\title{
Comparative Effects of Organic and Inorganic Seed Treatments on the Viability and Vigour of Sesame Seeds in Storage
}

\author{
K. O. Oyekale ${ }^{1}$, C. C. Nwangburuka ${ }^{1}$, O. A. Denton ${ }^{1}$, D. S. Daramola ${ }^{1}$, J. A. Adeyeye ${ }^{1}$ \& A. O. Akinkuotu ${ }^{1}$ \\ ${ }^{1}$ Department of Agriculture and Industrial Technology, Babcock University, Ilishan-Remo, Nigeria \\ Correspondence: K. O. Oyekale, Department of Agriculture and Industrial Technology, Babcock University, \\ Ilishan-Remo, Nigeria. E-mail: kenoye3@yahoo.com
}

Received: May 22, 2012 Accepted: June 11, 2012 Online Published: August 8, 2012

doi:10.5539/jas.v4n9p187 URL: http://dx.doi.org/10.5539/jas.v4n9p187

\begin{abstract}
This study was undertaken to determine the storability of pre-treated sesame seeds and to compare the effects of inorganic and organic seed treatments on the viability and vigour of sesame seeds during storage. Two hundred grammes of sesame seeds were treated separately with recommended dosages of Neem leaf powder (NLP), Dress force powder (DFP), Dry pepper powder (DPP) and untreated seeds being the control; each treatment placed in air-tight container and stored in a wooden cabinet at average ambient conditions of $26.5^{\circ} \mathrm{C}$ and $80 \%$ RH for a period of 18 weeks. Completely randomized design was used for the experiment, with storage time and seed treatment as factors. Samples were drawn from storage at interval of two weeks and tested for seed viability and seedling vigour. Seed germination, seedling vigour index, speed of germination and rate of germination were evaluated. Analysis of variance (ANOVA) was carried out on the data collected, and treatment means were separated using Duncan's Multiple Range Tests (DMRT). Correlation analysis was also carried out to ascertain the kinds of relationships that exist among the variables evaluated. Observations showed that NLP and DPP treatments had better mean seed germination of $89.53 \%$ and $82.35 \%$ respectively compared to DFP (46.47\%) and control (80.76). NLP also enhanced better seedling vigour index (339.24) throughout the strorage time compared to DFP (99.74). It is therefore recommended that natural botanicals like NLP could be adopted for short and medium term storage of sesame seeds; as it maintaned seed viability and seedling vigour optimally among other treatments.
\end{abstract}

Keywords: seed viability, seedling vigour, seed treatment, seed storage

\section{Introduction}

Sesame (Sesamum indicum L.) is an erect, annual plant; which belongs to the family Pedaliaceae. Its cultivation dated back to the early centuries, when it was cultivated for its seeds; which are used as food and as a good source of high quality oil. The first written records of this crop dated back to 3,000 BC; when Babylonians and Egyptians use sesame oil and sesame flour for household recipes (Filippone, 2006). The demand for sesame seed and its products is growing both at the National and International levels, and so huge market potential exists for sesame seeds. Owing to its previous status as a minor crop, there has been little research efforts on the crop (Onyibe et al., 2002).

Seed deterioration starts immediately after a crop has attained the physiological maturity stage. Thus, in order to prevent the quantitative and qualitative losses due to several biotic and abiotic factors during storage, several methods are being adopted such as seed treatment with suitable chemicals or plant products, as well as seed storage in safe containers (Abdul-Baki \& Anderson, 1973).

Roberts (1972) reported that seed deterioration during storage was due to the damage in cell membrane and other chemical changes in the seed system such as the protein and nucleic acid accumulation. Such degenerative changes result in complete disorganization of membranes and cell organells and ultimately causing death of the seed and loss of viability. Villiers (1980) opined that the most common and consistent ultra-structural changes in all the cell organelles was the loss in integrity of membranes, which invariably leads to increased seed deterioration especially during storage.

Harrington (1960) reported that for every one percent moisture decline and for each $5^{\circ} \mathrm{C}$ decrease in temperature the storage period will be doubled. In open and pervious containers, seed moisture content is determined by RH of the surrounding atmosphere and temperature of the storage environment. Roberts (1961) said that seeds stored 
in ambient conditions loose their viability and vigour very fast due to changes in storage conditions of temperature and relative humidity.

The storability of seeds is also influenced by the type of packaging material. Seeds stored in moisture-proved sealed containers provide suitable environment for storage, offer protection against contamination and also acts as a barrier against the escape of seed treatment chemicals than in moisture pervious containers (Nagaveni, 2005). Miyagi (1966) dried seeds of onion, carrot, cabbage, cucumber and tomato in dessicator and stored in moisture vapour-proof resistant and impervious containers. Higher viability and vigour was retained for longer period in moisture-proof containers followed by moisture resistant and impervious containers respectively.

Seed treatment with chemicals has been reported to be very effective in maintaining seed quality because it hinders the activities of storage pests and fungi (Gupta et al., 1989). Bhattacharya and Basu (1990) stated that dry dressing of pea seeds with $\mathrm{CaOCl} 2$ at $3 \mathrm{~g} / \mathrm{kg}$ of seeds retained higher vigour (5693) and viability (83\%) in ordinary storage for nine months as compared to control (2999 and 64\% respectively).

Seed treatment of chilli with thiram improved emergence and untreated seeds showed lowest emergence after 10 months of storage (Koteshwar-Rao et al., 1962). Siddaramaiah et al. (1979) observed the improvement in germination of peanut seeds treated with carbendazim, thiram, difalton, fentin acetali and triademeton. Muthuswamy et al. (1983) reported that among all the fungicides tested for chilli, captan (4 g/kg), sulphur dust $(4 \mathrm{~g} / \mathrm{kg})$, bavistin $(2 \mathrm{~g} / \mathrm{kg})$, vitavax $(2 \mathrm{~g} / \mathrm{kg})$ and benlate (benomyl, $4 \mathrm{~g} / \mathrm{kg})$ recorded higher germination compared to the untreated seeds. Gupta et al. (1989) reported that onion seeds treated with different chemicals viz., thiram, captan, captafol, and cytozyme retained the germination upto 12 months Dhyani et al. (1991) revealed that the seed treatment with captafol, thiram, aureofungin, topsin and vitavax each at 0.3 per cent concentration of seed weight improved seed germination and seedling length of chilli. Reddy and Reddy (1994) also treated the seeds of eggplant with thiram $(2.5 \mathrm{~g} / \mathrm{kg})$, delson $(1 \mathrm{ml} / \mathrm{kg})$ and captan $(2.5 \mathrm{~g} / \mathrm{kg})$ and observed that the thiram maintained higher germination up to 21 months of storage.

In recent years however, attempts have been made to replace synthetic (inorganic) seed treatment chemicals with organic materials of plant origin which are cheaper, safer and eco-friendly. Among the various methods followed, use of botanicals has been a traditional method and is being given much attention.

Parashivamurthy (1994) found that bean seeds treated with neem oil had increased viability (97\%) and seedling vigour (1240) over untreated control (49\%, 810 respectively) after storage of 240 days. Nargis (1995) reported that pelleting of tomato seeds with pongamia and arappu leaf powder showed better performance in laboratory and field conditions compared to control. Pal and Basu (1995) reported that wheat seeds treated with neem leaf powder at $2 \mathrm{~g}$ per $\mathrm{kg}$ of seed recorded maximum germination and seedling vigour after 7 months of storage under ambient condition. Sharma (1995) recommended treatment of maize seeds with neem leaf powder $(100 \mathrm{~g} / \mathrm{kg})$ and ash $(10 \mathrm{~g} / \mathrm{kg})$ for effective reduction in percent seed damage during storage. Ogunwolu and Odunlani (1996) reported that cowpea seeds treated with neem leaf powder $(3 \mathrm{~g} / \mathrm{kg})$ seeds showed reduced bruchid infestation after five months of storage. Anil et al. (1998) observed that soybean seeds treated with neem products and untreated seeds did not show any significant differences in germination. But seed treatment controlled association of mycoflora up to 120 days of storage period. Hossain et al. (1999) observed that soybean seeds coated with neem leaf powder showed excellent control of seed borne disease of colletotrichum dematum and maintained better seed health during the storage period. Arati (2000) reported that Bengalgram seeds treated with neem leaf powder recorded higher germination $(65.91 \%)$ and vigour index (1282) compared to control at the end of 10 months of storage period. Maraddi (2002) observed cowpea seeds treated with neem leaf powder $(5 \mathrm{~g} / \mathrm{kg})$ recorded higher germination (39.5\%) and vigour index (1072) compared to control $(34.2 \%$ and 864 , respectively) at the end of 10 months of storage period.

The use of botanicals as seed pre-treatment is now receiving much attention these days because of its proven advantages over the synthetic option. This work was therefore necessary to practically and technically investigate some of these earlier works; with reference to the introduction of some new and unproven botanicals.

The major objective of the study is to evaluate the storability of treated and untreated sesame seeds, while the specific objectives are:

1) To determine the comparative effects of selected organic and inorganic seed treatments on the seed viability and seedling vigour of sesame seeds in storage.

2) To monitor the deterioration and agronomic quality of treated sesame seeds over a period of time. 


\section{Materials and Methods}

The experiment was conducted at the laboratory of the Department of Agriculture and Industrial Technology, Babcock University Ilishan-Remo, Nigeria between October 2011 and February 2012. The design used was completely randomized design (CRD), with storage time and seed treatment as factors.

\subsection{Seed and Seed Source}

The crop seed used for this experiment is benniseed / sesame (Sesamun indicum). One variety of the crop identified as NCRIBEN01 (530-6-10) was obtained from the open market, properly cleaned and evaluated for initial quality.

\subsection{Initial Seed Quality Evaluation}

Prior to seed treatment, about $5 \mathrm{~g}$ of the seed was tested for different quality parameters: moisture content (\%), seed germination (\%), and seedling vigour.

\subsection{Seed Treatment and Storage}

Three seed treatments and a control were used in the experiment. This included dress force powder (synthetic chemical), botanicals (neem leaf powder and dry pepper powder) and an untreated control.

The seed dressing chemical and the two botanicals were thoroughly mixed with the seeds at the following recommendations: Neem Leaf Powder at 75g per kg of seed (Abdul-Rafiu, 2006), Dry Pepper Powder at $75 \mathrm{~g}$ per $\mathrm{kg}$ of seed (Abdul-Rafiu, 2006), Dress Force Powder at 5g per kg of seed (Oyekale, 2000), and an untreated control. These were filled into plastic containers and kept in a wooden cabinet (with ambient conditions of $26.5^{\circ} \mathrm{C}$ and $80 \% \mathrm{RH}$ ) at the crop laboratory of the Department of Agriculture and Industrial Technology, Babcock University Ilishan-remo Ogun state. The storage lasted for a period of 5 months (October $2011-$ February 2012).

\subsection{Seed Viability and Seedling Vigour Evaluation}

Seed samples were drawn from the containers at two weeks interval and tested for viability and vigour.

\subsubsection{Seed Germination Assessment}

One hundred seeds in five replications were taken from each treatment, and germination test was conducted using petri-dishes with filter paper placed in them. The number of normal seedlings were counted at two days interval and cumulative germination obtained at the 8th day. Percent seed germination was then expressed as number of seed germinated over total no of seed planted (expressed in percentage).

\subsubsection{Seedling / Plumule Length Measurement}

This was obtained with the aid of a ruler; by measuring the length (in $\mathrm{cm}$ ) of the seedling from the base of the plant above the substrate to the apex of the last leaf on the $8^{\text {th }}$ day.

\subsubsection{Seedling Vigour Index}

The vigour index of seedling was calculated by adopting the method suggested by Abdul-Baki and Anderson (1973), and expressed as:

$$
\text { Seedling vigour index }(\mathrm{VI})=\text { Germination }(\%) \text { x Seedling length }(\mathrm{cm})
$$

\subsubsection{Speed of Germination}

This was obtained using the formula:

$$
\text { i.e. } \quad \frac{\text { no of seeds at first count }}{\text { day of first count }}+\frac{\text { no of seeds at second count }}{\text { day of second count }}+\cdots \frac{\text { no of seeds at final count }}{\text { day of final count }}
$$

(Adebisi and Oyekale, 2005)

\subsubsection{Rate of Germination}

This was estimated using the formula:

(Daniel, 2007)

$$
\text { i.e. } \quad 1 / t_{n}\left(\sum G_{n}\right)
$$

where $t_{n}=$ total time taken,

$\sum \mathrm{G}_{\mathrm{n}}=$ cumulative germination count. 


\subsection{Statistical Analysis}

The data collected from the experiment were analyzed using SAS (Statistical Analysis Software) version 9.1 (SAS, 1999).

Analysis of variance (ANOVA) was carried out; with storage time $(\mathrm{P})$ and seed treatment $(\mathrm{T})$ as factors, in order to be able to determine if the time and treatment were significant on the parameters evaluated. Means from ANOVA were separated using Duncans' Multiple Range Test (DMRT), to be able to detect differences among the time periods and the treatments. Correlation analysis was also carried out on the parameters evaluated to ascertain the kind(s) of relationships that exist among the variables.

\section{Results and Discussion}

\subsection{Analysis of Variance of the Seed Viability and Seedling Vigour Variables of the Stored Sesame Seeds}

Means square from analysis of variance of seed viability and seedling vigour variables (seedling length, seedling vigour index, speed of germination, rate of germination) for the stored sesame seeds are presented in Table 1. All the variables were highly significant $(p \leq 0.01)$ on storage time as well as the seed treatments. Also, all the variables evaluated were highly significant on the interaction of storage time and seed treatment. This indicates that storage time, treatment, and interactions between storage time and treatment had significant effect on the seed viability and seedling vigour variables. This is in line with the work of Nagaveni (2005), who reported that interactions between storage time and seed treatments were highly significant for onion seed. Replication was highly significant $(\mathrm{p} \leq 0.01)$ on seedling vigour index and significant $(\mathrm{p} \leq 0.05)$ on percentage germination, speed of germination and rate of germination; but not significant for seedling length.

Table 1. Means square from analysis of variance for seed viability and seedling vigour variables of stored sesame seeds

\begin{tabular}{lllllll}
\hline Sov & Df & Germperc & Seedlt & Svi & Sog & Rog \\
\hline Storage time(p) & 7 & $887.96^{* *}$ & $1.48^{* *}$ & $2575.80^{* *}$ & $499.12^{* *}$ & $14.41^{* *}$ \\
Trt(t) & 3 & $14824.44^{* *}$ & $19.61^{* *}$ & $447686.36^{* *}$ & $6312.27^{* *}$ & $228.60^{* *}$ \\
p x t & 21 & $273.60^{* *}$ & $0.26^{* *}$ & $3852.07^{* *}$ & $110.89^{* *}$ & $4.31^{* *}$ \\
Rep & 4 & $76.14^{*}$ & $0.04^{\text {ns }}$ & $1945.97^{* *}$ & $36.24^{*}$ & $1.15^{*}$ \\
Error & 124 & 24.79 & 0.04 & 546.59 & 11.70 & 0.43 \\
Total & 159 & & & & & \\
\hline Cv (\%) & & 6.66 & 6.29 & 9.20 & 7.12 & 7.03 \\
\hline
\end{tabular}

Key: *Significant at $0.05,{ }^{*}$ Significant at $0.01, \mathrm{~ns}=$ Not Significant, sov: Source of Variation, df: Degree of Frequency, seedlt: Seedling Length, germperc: Germination Percentage, svi: Seedling Vigour Index, sog: Speed of Germination, rog: Rate of Germination trt: Treatment, rep: Replication, Trt: treatment.

\subsection{Means of Seed Viability and Seedling Vigour Variables of Sesame during Storage}

Results from Table 2 show that there were no statistical differences in percent seed germination from weeks 8 to 12 and weeks 15 to 18 , with highest mean seed germination week 2 and lowest at week 18, similar to the works of (Usha et al., 1990) in cowpea where the lowest germination percentage was recorded at the final germination test. Differences were also observed in seedling length where it was highest at week 18 and lowest at week 2. Seedling vigour index, was highest between weeks 10 and 12 and consistently moderate for other storage periods. Speed of germination was also significantly higher at the second week and lowest at week 18; while the rate of germination similarly was highest at week 2 and reduced significantly from weeks 15 to 18. Similar results were obtained by Singh and Dadlani (2003) who recorded higher germination percentage with soybean seeds. 
Table 2. Means of seed viability and Seedling vigour parameters of sesame seeds stored for 18 weeks

\begin{tabular}{llllll}
\hline Storagetime(was) & Germperc & seedlt & Svi & Sog & Rog \\
\hline 2 & $87.10 \mathrm{a}$ & $2.77 \mathrm{e}$ & $246.99 \mathrm{~b}$ & $56.19 \mathrm{a}$ & $10.88 \mathrm{a}$ \\
4 & $80.10 \mathrm{~b}$ & $3.02 \mathrm{~d}$ & $250.56 \mathrm{~b}$ & $51.91 \mathrm{~b}$ & $10.01 \mathrm{~b}$ \\
6 & $70.95 \mathrm{de}$ & $3.21 \mathrm{c}$ & $246.67 \mathrm{~b}$ & $46.35 \mathrm{~d}$ & $8.87 \mathrm{de}$ \\
8 & $75.90 \mathrm{c}$ & $3.39 \mathrm{~b}$ & $270.31 \mathrm{a}$ & $49.28 \mathrm{c}$ & $9.44 \mathrm{c}$ \\
10 & $75.95 \mathrm{c}$ & $3.40 \mathrm{~b}$ & $270.81 \mathrm{a}$ & $49.52 \mathrm{c}$ & $9.49 \mathrm{c}$ \\
12 & $73.50 \mathrm{~cd}$ & $3.26 \mathrm{c}$ & $254.49 \mathrm{~b}$ & $47.86 \mathrm{~cd}$ & $9.19 \mathrm{~cd}$ \\
15 & $68.40 \mathrm{ef}$ & $3.50 \mathrm{ab}$ & $256.04 \mathrm{ab}$ & $43.10 \mathrm{e}$ & $8.55 \mathrm{ef}$ \\
18 & $66.35 \mathrm{f}$ & $3.62 \mathrm{a}$ & $243.52 \mathrm{~b}$ & $40.15 \mathrm{f}$ & $8.2 \mathrm{f}$ \\
\hline
\end{tabular}

Key: means with the same letter along the column are not significantly different from one another. germperc: Germination Percentage, seedlt: Seedling Length, svi: Seedling Vigour Index, sog: Speed of Germination, rog: Rate of Germination, was: weeks after storage.

\subsection{Means of Seed Viability and Seedling Vigour Variables of Four Sesame Seed Treatments}

Result from Table 3 shows statistical variations were noticed in all variables, neem leaf powder treatment recorded highest statistical variation while dress force powder treatment had the lowest where no statistical difference were noticed in dry pepper powder treatment and control treatment for variables; germination percentage, speed of germination and rate of germination. For seedling length and Seedling vigour index, statistical differences were noticed in all variables, where it was highest at neem leaf powder treatment, and lowest at dress force powder treatment. This result is in contrast to the work of Gupta et al. (1989), who reported that seed treatment with chemicals is found to be more useful in storage for maintaining better seed quality. Neem leaf powder also enhanced better seedling vigour index maintenance throughout the storage time; and this is line with the works of Pal and Basu (1995), who reported that wheat seeds treated with neem leaf powder at $2 \mathrm{~g}$ per $\mathrm{kg}$ of seed had maximum germination and seedling vigour after 7 months of storage under ambient conditions. Maraddi (2002) also observed that cowpea seeds treated with neem leaf powder $(5 \mathrm{~g} / \mathrm{kg})$ had higher germination (39.5\%) and vigour index (1072) compared to control (34.2\% and 864, respectively) at the end of 10 months of storage period.

Table 3. Means of seed viability and seedling vigour parameters of four seed treatments for stored sesame seeds

\begin{tabular}{llllll}
\hline Trt & Germperc & Seedlt & Svi & Sog & Rog \\
\hline Nlp & $89.53 \mathrm{a}$ & $3.78 \mathrm{a}$ & $339.24 \mathrm{a}$ & $57.66 \mathrm{a}$ & $11.14 \mathrm{a}$ \\
$\mathrm{dpp}$ & $82.35 \mathrm{~b}$ & $3.42 \mathrm{c}$ & $282.38 \mathrm{c}$ & $52.95 \mathrm{~b}$ & $10.30 \mathrm{~b}$ \\
$\mathrm{dfp}$ & $46.47 \mathrm{c}$ & $2.45 \mathrm{~d}$ & $99.74 \mathrm{~d}$ & $29.57 \mathrm{c}$ & $5.81 \mathrm{c}$ \\
con & $80.76 \mathrm{~b}$ & $3.64 \mathrm{~b}$ & $295.33 \mathrm{~b}$ & $51.99 \mathrm{~b}$ & $10.07 \mathrm{~b}$ \\
\hline
\end{tabular}

Key: means with the same letter along the column are not significantly different from one another.

Nlp: Neem Leaf Powder, dpp: Dry Pepper Powder, dfp: Dress Force Powder, con: Control, seedlt: Seedling Length, germperc: Germination Percentage, svi: Seedling Vigour Index, sog: Speed of Germination, trt: Treatment, rog: Rate of Germination.

\subsection{Seed Viability of Stored Sesame under Four Seed Treatments}

In Figure 1, the highest percentage germination over all treatments was recorded for neem leaf powder treatment at two weeks. This was followed by dry pepper powder treatment, control treatment and dress force powder treatment. Dress force powder-treated seeds had the lowest germination at week 15; while seed germination was also lowest at week 18 for control, dry pepper powder and neem leaf powder treatments. This is in line with the work of Arati (2000), who reported that Bengalgram seeds treated with neem leaf powder recorded higher germination (65.91\%) compared to control at the end of 10 months of storage period. Hence, seed germination reduced significantly in all the treatments throughout the storage time, but at diferent rates. 

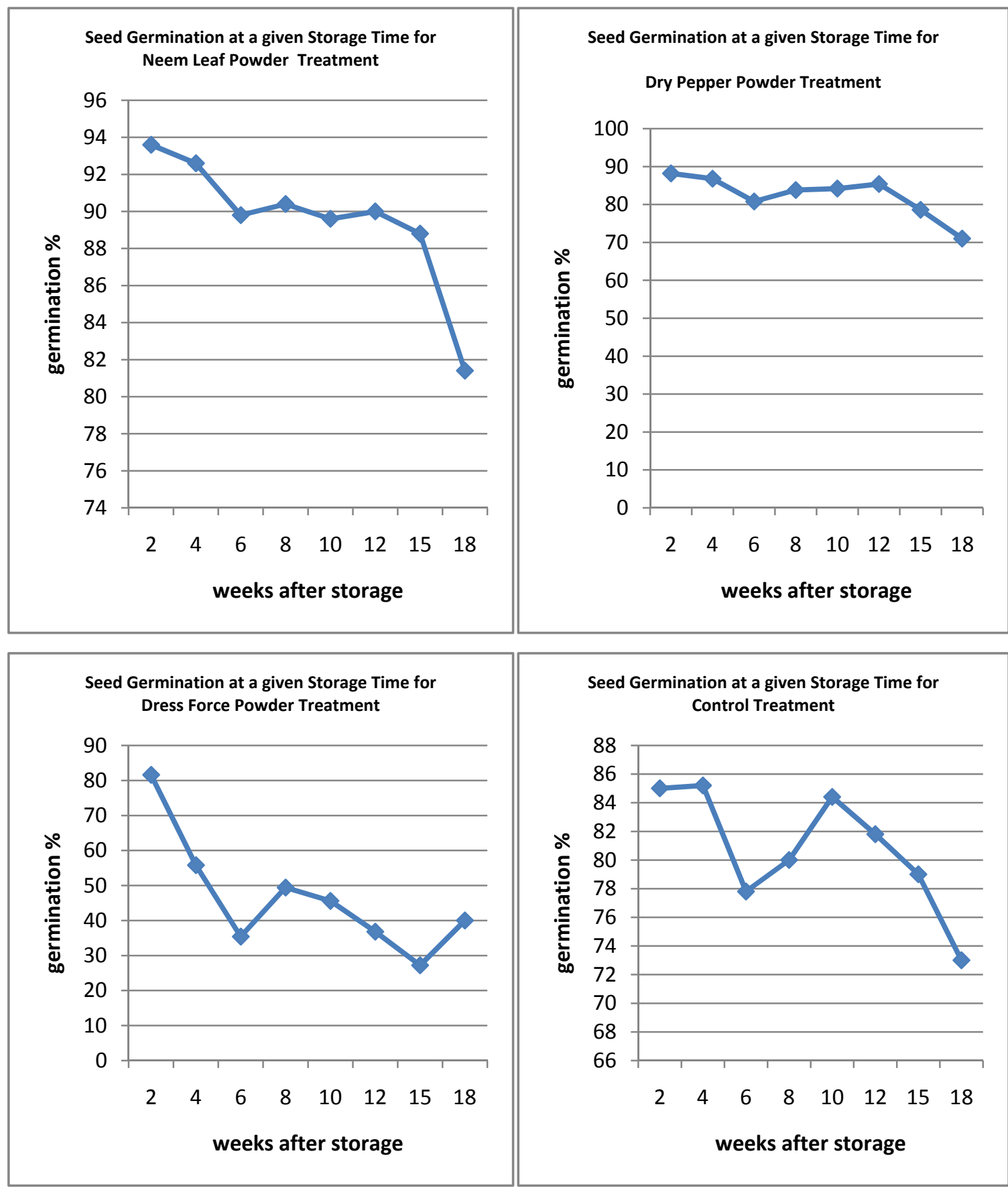

Seed Germination at a given Storage Time for Control Treatment

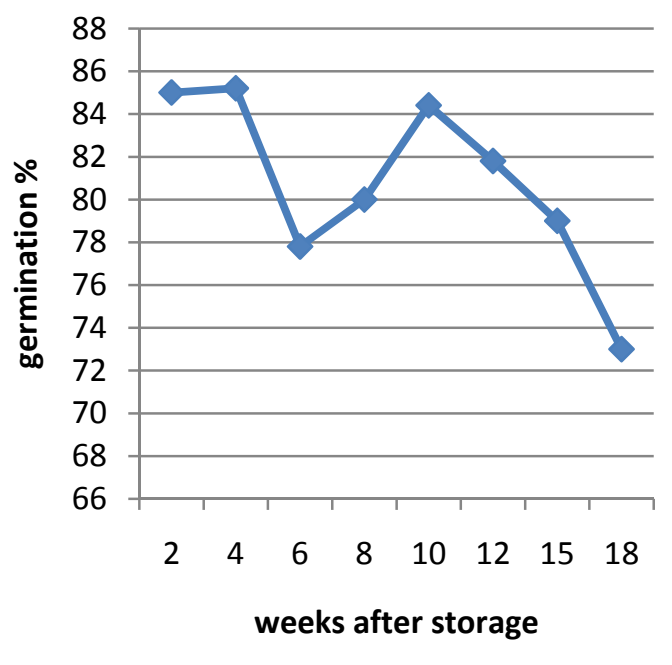

Figure 1. The germination performance of sesame seed during storage for 18 months under four seed pre-treatments

\subsection{Seedling Vigour of Stored Sesame Seed under Four Seed Treatments}

In Figure 2, the highest seedling vigour index was recorded for neem leaf powder treatment at week 10, this was followed by dry pepper powder treatment at week 8 , control treatment at week 15 and dress force powder treatment at week 2; while dress force powder had the lowest seedling vigour at week 15, lowest at weeks 2 for the control and neem leaf powder treatment, and lowest at week 18 for dry pepper powder. Arati (2000) reported that Bengalgram seeds treated with neem leaf powder recorded higher vigour index (1282) compared to control at the end of 10 months of storage period. 

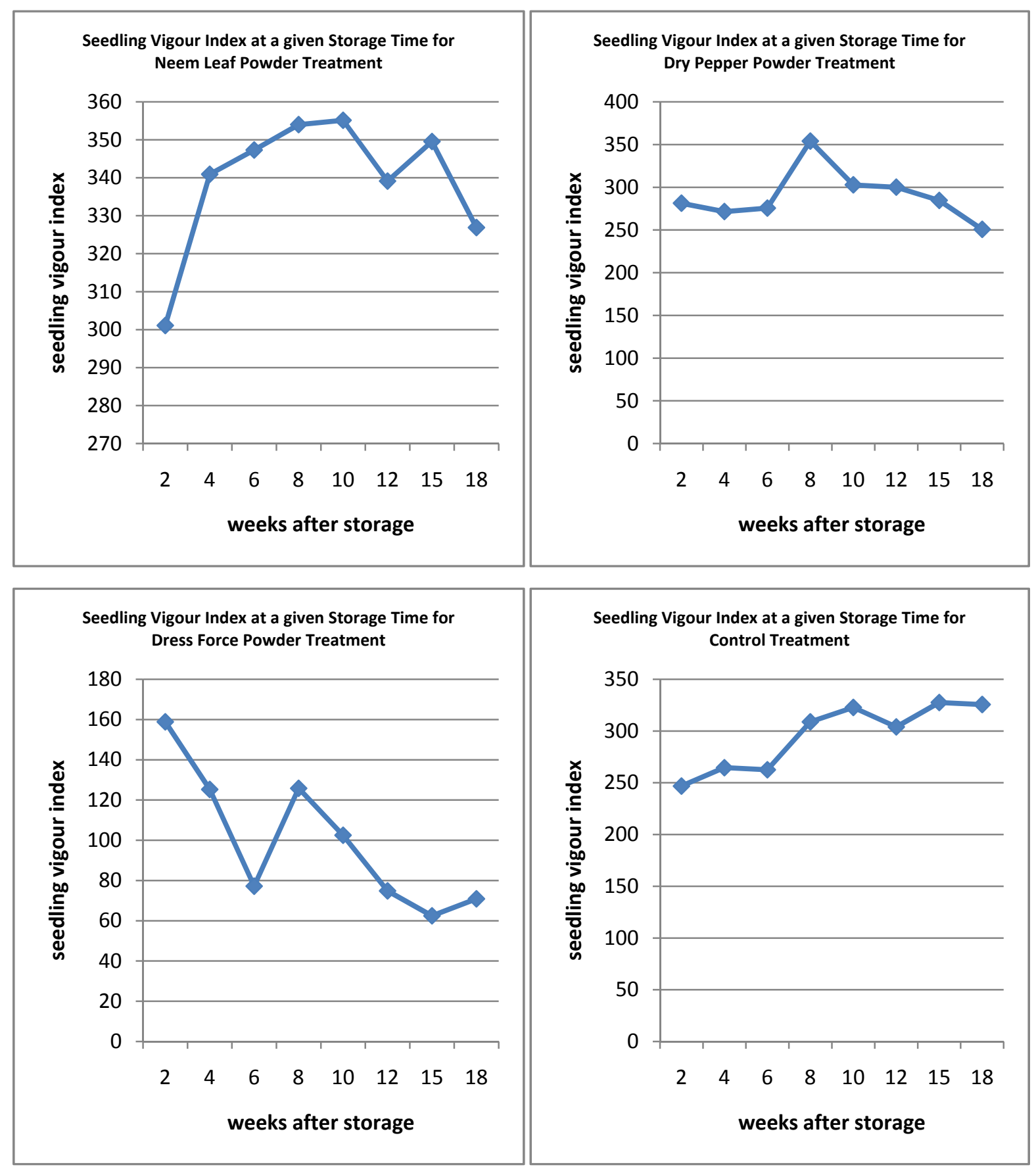

Figure 2. The seedling vigour performance of sesame during storage for 18 months under four seed pre-treatments

\subsection{Relationships among the Seed Viability and Seedling Vigour Variables Evaluated}

Table 4 shows the relationships among the seed viability and seedling vigour variables evaluated for the stored sesame seed. The relationship between germination percentage and seedling length, seedling vigour index, speed of germination, and rate of germination was highly and positively significant; which indicates that an increase in seed germination performance leads to significant increase in all these other variables. The relationship between seedling length and seedling vigour index, speed of germination, and rate of germination was also highly positively significant; which also indicates that an increase in seedling length performance leads to significant increase in all other variables. The relationship between seedling vigour index, speed of germination and rate of germination was highly positively significant; and this also indicates that increase in seedling vigour index leads to significant increase in all the other variables. There was also significant and positive relationship between 
speed of germination and rate of germination; and this as well indicates that an increase in the speed of germination of the stored sesame seed increases its rate of germination. The interaction between these variables implies that an increase in the value of any of the variables leads to increase in all other variables. This kind of relationship was reported in the work of Adebisi and Oyekale (2005), who evaluated a variety of pre-treated okra seeds in storage and reported significant positive relationships among the seed quality attributes.

Table 4. Relationships among five seed viability and seedling vigour parameters of stored sesame seeds

\begin{tabular}{llllll}
\hline & Germperc & Seedlt & Svi & Sog & rog \\
\hline Germperc & - & $0.6610^{* *}$ & $0.9000^{* *}$ & $0.9922^{* *}$ & $0.9974^{* *}$ \\
seedlt & - & - & $0.9001^{* *}$ & $0.6371^{* *}$ & $0.6537^{* *}$ \\
svi & - & - & - & $0.8880^{* *}$ & $0.8957^{* *}$ \\
sog & - & - & - & - & $0.9911^{* *}$ \\
rog & - & - & - & - & - \\
\hline
\end{tabular}

Key: ** Significant at 0.01, seedlt: Seedling Length, germperc: Germination Percentage, svi: Seedling Vigour Index, sog: Speed of Germination, rog: Rate of Germination.

\section{Conclusions}

Among the seed treatments, neem leaf powder and dry pepper powder (which are natural botanicals) recorded higher seed quality parameter throughout the storage period compared to dress force powder (synthetic) and the untreated control. Sesame seeds treated with neem leaf powder and dry pepper powder maintained higher germination $(89.53 \%$ and $82.35 \%$ ) repectively for 18 weeks, while dress force powder was unable to properly maintain seed germination (46.47\%). Also, neem leaf powder treatment recorded higher seedling vigour (339.24), while dress force powder recorded the lowest seedling vigour index (99.74). This implies that dress force powder treatment could not therefore properly maintain seed germination and seedling vigour for all the seed quality attributes within the storage period, while neem leaf powder treatment which is an organic material was able to preserve seed viability and seedling vigour for an appreciable time during sesame seed storage.

Based on the results of this study, it may be concluded that sesame seeds could be treated with neem leaf powder and/or dry pepper powder to maintain seed germination (more than $80 \%$ ) for up to 18 weeks. Seed treatment with neem leaf powder is specifically recommended for pre-treatment storage of sesame seeds, as it maintained seed viability and seedling vigour optimally among all other treatments. More botanicals (different plant source and different parts of the plant - leaves, extracts etc) could however still be tried for sesame seed storage and with diferent varieties of the crop.

\section{References}

Abdul-Baki, A. A., \& Anderson, J. D. (1973). Physiological and biochemical deterioration of seed. In Seed Biology (II Ed): Kozlowski, T. T., Academic Press, New York, London, pp. 283-315.

Abdul-Rafiu, A. M. (2006). Effect of selected Botanicals on Maize storage weevils during storage under ambient conditions. Masters of Agric. Thesis. University of Agric. Abeokuta. pp. 90.

Adebisi, M. A., \& Oyekale, K. O. (2005). Effect of Seed Treatments and Storage Containers on the Maintenance of Viability of Okro Seed. ASSET Series A., 5(1), 81-89.

Anil, K. N., Gaur, A., Sunk, S. S. K., \& Devkumar, C. (1998). Performance of neem products on storability of soybean. Seed Research, 26(2), 138-146.

Arati, P. (2000). Influence of containers and seed treatment on storability of chickpea. M.Sc. (Agric.) Thesis. University of Agricultural Sciences, Dharwad. pp. 255.

Bhattacharya, S., \& Basu, A. (1990). Retention of vigour and viability of stored pea (Pisum sativum L.) seed. Indian Agri., 34, 187-193.

Daniel, I. O. (2007). Longevity of maize seeds during low input storage under ambient condition in South-western Nigeria. Journal of Tropical Agriculture, 45(1-2), 42-45.

Dhyani, A. P., Sati, M. C., \& Khulbe, R. D. (1991). Seed health testing of red pepper and bell peper with special reference to the pathogenesity and control of Mycrothecium Verrucaria. International Journal of Tropical Plant Diseases, 9, 207-220.

Filippone, P. T. (2006). The history of sesame seeds as food. Foodhistory.about.com. 
Gupta, R. P., Ushamehra, Pandey, U. B., \& Mehra, U. (1989). Effect of various chemicals on viability of onion seed in storage. Seed Research, 17(1), 99-101.

Gupta, S. P., Madan, P. S., \& Kaur, J. (1976). Effect of seed size on seed yield and seed quality in wheat. Seeds and Farms, 13, 11-13.

Harrington, J. F. (1960). Seed storage viability. Boyce Thompson Institute of Plant Research, 17, 87-103.

Hossain, I., Suratuzzaman, M., \& Khalil, M. I. (1999). Seed heath of soybean and control of seed born fungi with botanicals. Bangladesh Journal of Training and Development, 12(2), 99-105.

Koteshwar-Rao, O., Srihari-Rao, K., \& Govind-Rao, P. (1962). Effect of seed treatment of chilli with organic fungicides in improving germination. Andhra Agriculture Journal, 9, 55-59.

Maraddi, B. (2002). Influence of growth regulators on seed yield and quality and seed treatments on storability of cowpea cv. C-252, M.Sc. (Agri.) Thesis. University of Agricultural Sciences, Dharwad. pp. 216.

Miyagi, K. (1966). Effect of moisture proof packing on maintenance of viability of vegetable seeds. Proceedings of International Seed Testing Association, 31, 213-220.

Muthuswamy, S., Padmanabbhan, D., \& Nagarajan, R. (1983). Efficacy of fungicides on the viability of chilli seeds. Pesticide, 17, 23-28.

Nagaveni, P. K. (2005). Effect of storage conditions, packing material and seed treatment on viability and vigour of onion seeds. M.Sc. (Agri.) Thesis. University of Agricultural Sciences, Dharwad. pp. 235.

Nargis, S. (1995). Influence of pelleting, magnetic treatments and radiation on the performances of differentially aged seeds in tomato (Lycopersicon esculentum Mill.) cv. PKM-1, M.Sc. (Agri.) Thesis, Tamil Nadu agricultural University, Coimbatore. pp. 256.

Ogunwolu, E. O., \& Odunlani, A. T. (1996). Suppression of seed bruchid (Callosobruchus maculatus development and damage on cowpea (Vigna ungiculata) with Zantoxylem zantoxyloider L. (Rutaceae) root bark powder when compared to neem seed powder and primiphosmethyl. Crop Protection, 15, 603-607.

Onyibe, J. E., Tologbonshe, E. B., \& Ubi, E. O. (2002). Beniseed production and utilization in Nigeria. Extension bulletin No. 154, Horticulture Series, No. 5.

Oyekale, K. O. (2000). Effects of seed treatment and storage container on the maintenance of viability and vigour of okra seeds. B. Agric. Thesis. University of Agric., Abeokuta Nigeria. pp. 45.

Pal, P., \& Basu, R. N. (1995). Effect of powdered chilli, turmeric and neem leaf on pre and post storage germinability of wheat seed. Indian Agriculture, 57(4), 267-271.

Parashivamurthy, K. M. (1994). Role of chemical seed treatment on seed quality and longevity of soybean. M.Sc. (Agri.). Thesis. University of Agricultural Sciences, Bangalore. pp. 159.

Reddy, S. V., \& Reddy, M. B. (1994). Effect of seed protectants on storability of eggplant (Solanum melongena L.) seed. Seed Research, 22, 181-183.

Roberts, E. H. (1961). The viability of rice seed in relation to temperature, moisture content and gaseous environment. Annals of Botany, 25, 381-390.

Roberts, E. H. (1972). Cytological, genetic and metabolic changes associated with loss of viability. pp. 253-306. In E. H. Roberts (ed.). Viability of seeds. Chapman and Hall limited, London.

SAS. (1999). Statistical Analysis Software (SAS). Systems for windows. SAS Users' Guide; Statistics, Version 9.1. SAS Institute Inc. Cary. NC, USA. pp. 1028.

Sharma, R. K. (1995). Neem leaf powder and cobash against Rhyzopertha dominica (F), in stored maize. Indian Journal of Entomology, 57, 15-17.

Siddaramaiah, A. L., Krishna-Prasad, K. S., \& Hegde, R. K. (1979). Effectiveness of seed dressing chemicals against crown rot of peanut seeds. Pesticides, 13, 28-29.

Singh, K. K., \& Dadlani, M. (2003). Effect of packaging on vigor and viability of soybean (Glycine max (1.) Merrill) seed during ambient storage. Seed Res., 31(1), 27-32.

Usha, H., Javaregowda, S., \& Ramaiah, H. (1990). Influence of containers, chemicals and byproduct treatments on storability of cowpea (Vigna unguiculata) and horsegram (Delieos bifloera) seeds. Leg. Res., 13(1), 13-16.

Villiers, T. A. (1980). Ageing and the longevity of seeds on field conditions. Seed Eco., pp. 265-287. 